\title{
Review
}

\section{Rethinking Alzheimer's Disease Therapy: Are Mitochondria the Key?}

\author{
Maria Ankarcrona ${ }^{\mathrm{a}, *}$, Francesca Mangialasche ${ }^{\mathrm{b}, \mathrm{c}}$ and Bengt Winblad ${ }^{\mathrm{a}}$ \\ ${ }^{a}$ KI-Alzheimer's Disease Research Center, Karolinska Institutet, Department of Neurobiology, Care Sciences and \\ Society (NVS), Huddinge, Sweden \\ ${ }^{\mathrm{b}}$ Aging Research Center, Karolinska Institutet, Stockholm, Sweden \\ ${ }^{\mathrm{c}}$ Institute of Gerontology and Geriatrics, Department of Clinical and Experimental Medicine, University of \\ Perugia, Italy
}

Accepted 5 April 2010

\begin{abstract}
The number of people suffering from Alzheimer's disease (AD) is constantly increasing worldwide since humans live longer and age is the strongest risk factor for AD. Currently available medications for AD do not interfere with the progressive loss of synapses and neurons in the AD brain. Therefore, the development of disease modifying therapies is a major future goal. Mitochondria provide cellular energy and are crucial for proper neuronal activity and survival. Mitochondrial dysfunction is evident in early stages of $\mathrm{AD}$ and is involved in $\mathrm{AD}$ pathogenesis. The development of drugs that protect mitochondria from damage is therefore a promising strategy for $\mathrm{AD}$ therapy. In this review, we will discuss current available medications for AD, drugs under clinical testing, and mitochondria as a novel drug target.
\end{abstract}

Keywords: Alzheimer's disease, drug target, mitochondria, therapy

\section{INTRODUCTION}

At present there are no disease modifying drugs for Alzheimer's disease (AD) on the market. Available drugs include acetylcholinesterase inhibitors and memantine, both of which target neurotransmission. The overwhelming current drug development targets the production or aggregation of amyloid- $\beta$ peptide $(\mathrm{A} \beta)$. However, maybe it is time to move from the idea of "one protein-one target-one drug" strategies to the development of drugs that affects organelles and have multiple targets as recently discussed by Bolognesi and colleagues [1]. Considering that AD is a complex dis-

\footnotetext{
*Correspondence to: Maria Ankarcrona, KI-Alzheimer's Disease Research Center, Karolinska Institutet, Department of Neurobiology, Care Sciences and Society (NVS), Novum 5th floor, SE-141 86 Huddinge, Sweden. Tel: +46858583617; Fax: +46858583610; E-mail: maria.ankarcrona@ki.se.
}

order, most likely caused by several different events, it is possible that drugs with a rich pharmacology and multiple targets will be most successful in clinical trials. This does not exclude targeting $\mathrm{A} \beta$ production or $\mathrm{A} \beta$ aggregation, which certainly has an important role in $\mathrm{AD}$ pathogenesis, but blocking only these processes obviously may not be sufficient to improve the disease, e.g., cognitive functions in $\mathrm{AD}$ patients.

In this review, we will discuss currently available medications for $\mathrm{AD}$ and drugs under clinical testing for $\mathrm{AD}$ and then focus on mitochondria as a drug target in AD. Functional mitochondria are crucial both for cell survival and death as they produce cellular energy in the form of ATP and are central in apoptotic signaling. Many lines of evidence suggest that mitochondria have an important role in neurodegenerative disorders and mitochondrial dysfunction has been shown in AD, Parkinson's disease, Huntington's disease, and amyotrophic lateral sclerosis [2]. Therefore the mitochon- 
drion has been suggested as a potential drug target in neurodegenerative disorders and drugs that affect various mitochondrial functions are under development.

\section{CURRENTLY AVAILABLE MEDICATIONS FOR AD: TARGETING NEUROTRANSMISSION}

$\mathrm{AD}$ is characterized by the progressive loss of basal forebrain cholinergic neurons, leading to reduction in transmission through cholinergic fibers involved in processes of attention, learning, and memory. Currently available medications for AD, acetylcholinesterase inhibitors (AChEIs) and memantine, aim to restore physiological levels of cholinergic and glutamatergic transmission, both impaired in AD brain. These drugs show efficacy during a certain period, however, the degeneration of neurons and loss of cognitive functions is unaffected and the state of patients worsen. AChEIs inhibit the enzymatic degradation of acetylcholine (ACh) and improve ACh deficit in AD. Donepezil, rivastigmine, and galantamine are AChEIs currently used for the treatment of mild and moderate AD. Donepezil also proved effective in severe $\mathrm{AD}$ [3] and is approved for all AD stages in several countries. Galantamine additionally modulates nicotinic receptors, while rivastigmine inhibits both AChE and butyrylcholinesterase. These mechanisms may also contribute to therapeutic efficacy. AChEIs seem equally effective in ameliorating symptoms of AD patients [4], while it is debatable whether AChEIs have disease-modifying effects. AChEIs can affect $\mathrm{A} \beta$ production and reduce $\mathrm{A} \beta$-induced toxicity [5]. AChEIs can also modulate expression of AChE isoforms and increase expression of nicotinic receptors, events associated with cognitive improvement in AD patients [5].

Excessive glutamate levels are toxic to neurons and are considered important in AD pathophysiology. Memantine is an non-competitive, voltage-dependent antagonist of NMDA glutamate receptors, blocking excessive glutamate levels (glutamatergic excitotoxicity) without interfering with normal glutamatergic transmission [6]. As monotherapy, memantine has shown positive effects on cognition, functional status, behavior, and global function in moderate-to-severe $\mathrm{AD}[7$, 8]. The drug also proved to be effective in combination with AChEIs [9,10]. As for AChEIs, a clear diseasemodifying effect for memantine is not evident, but the drug shows several potential neuroprotective properties including: i) prevention of $\mathrm{A} \beta$-induced neurotoxici- ty [6]; ii) modulation of protein-phosphatase-2A, which regulates tau phosphorylation, with consequent inhibition of neurofibrillary degeneration [11]; and iii) reduction of microglia-associated inflammation and stimulation of neurotrophic factor release from astroglia [12].

\section{DRUGS UNDER CLINICAL TESTING FOR AD THERAPY: TARGETING PROTEINS}

Abnormal misfolding and aggregation of $\mathrm{A} \beta$ and tau proteins leads to the two pathological hallmarks of AD: amyloid plaques and neurofibrillary tangles, respectively [13]. $\mathrm{A} \beta$ is generated by the sequential cleavage of amyloid $\beta$ protein precursor $(\mathrm{A} \beta \mathrm{PP})$ by $\beta$ - (BACE1) and $\gamma$-secretases [14]. Currently, development of disease-modifying therapy in AD is largely based on anti-amyloid strategies, with compounds targeting $\mathrm{A} \beta$ production (e.g., BACE1 inhibitors, $\gamma$ secretase inhibitors and modulators, and $\alpha$-secretase activators), aggregation and removal (e.g., active and passive immunotherapy).

Examples of drugs in clinical testing affecting BACE1 are the oral hypoglycemic drugs rosiglitazone and pioglitazone which stimulate the nuclear peroxisome proliferator-activated receptor gamma ( $\operatorname{PPAR} \gamma)$. These drugs reduce $\mathrm{BACE} 1$ and $\mathrm{A} \beta \mathrm{PP}$ expression and thus, indirectly, the production of $\mathrm{A} \beta$ [15]. Other ADrelated effects of PPAR $\gamma$ agonists are discussed under the paragraph "Impaired glucose uptake and insulin resistance" in this review. Among $\gamma$-secretase inhibitors (GSIs), semagacestat (LY450139) decreases plasma and central nervous system (CNS) A $\beta$ levels $[16,17]$ and is currently tested in Phase III randomized control trials (RCTs) [18]. Notch is another substrate for the $\gamma$-secretase complex and interference with Notch receptor signaling is responsible for the adverse effects of GSIs. However, Notch-sparing GSIs such as Begacestat (GSI-953), BMS-708163, NIC5-15, and PF3084014 have been developed and are being tested in humans [18].

Anti-aggregants are a chemically heterogeneous group of compounds able to bind $\mathrm{A} \beta$ monomers or oligomers. PBT2 is a "metal-protein attenuating compound" which binds to $\mathrm{A} \beta-\mathrm{Cu}$ (or $\mathrm{Zn}$ ) complexes. PBT2 prevents $\mathrm{A} \beta$ oligomerization, decreases soluble and insoluble brain $\mathrm{A} \beta$, and has positive effects on cognition in animal models [19]. Potentially beneficial therapeutic properties of PBT2 include its ability to increase neuronal accessibility for metal ions and to normalize $\mathrm{Zn}$ and $\mathrm{Cu}$ concentrations in the gluta- 
matergic synapse, restoring NMDA-receptor functioning and long term potentiation [19]. Another antiaggregant, now in Phase III RCT, is epigallocatechin-3gallate $(\mathrm{EGCg}) . \mathrm{EGCg}$ is a catechin from green tea able to promote the generation of the soluble $\mathrm{A} \beta \mathrm{PP}$ fragment $(\mathrm{A} \beta \mathrm{PP} \alpha)$ and to prevent $\mathrm{A} \beta$ aggregation [20]. EGCg shows other properties that could be therapeutic in $\mathrm{AD}$ : $\mathrm{EGCg}$ can activate protein kinase $\mathrm{C}$, that is involved in cell survival and apoptosis, in long term potentiation, and processes of memory consolidation [20]. EGCg also acts as antioxidant and seems to stabilize mitochondrial membrane potential, thus preserving mitochondria function [20].

Passive and active immunizations are therapeutic approaches to promote the clearance of soluble and aggregated $\mathrm{A} \beta$ in the CNS. The development of vaccines has been halted by serious adverse events that occurred with the first vaccine (AN-1972) [21]. The side effects of $\mathrm{AN}-1972$ were related to cytotoxic and/or autoimmune reactions. New vaccines against A $\beta$ (CAD106, ACC-001, V950, ACI-24, AFFITOPE AD01 and AD02) in Phase I/II RCTs mainly target the B-cell epitope, without stimulating T-cells. Passive immunotherapy includes humanized monoclonal antibodies (i.e., Bapineuzumab, Solanezumab) and polyclonal immunoglobulins (IVIg) which are now on Phase III RCTs in subjects with AD [18].

Results of the RCT on AN-1972 raise the importance of a critical reappraisal of the pathogenetic role of $\mathrm{A} \beta$ in AD. Some evidence of positive effects on cognition has been reported in subjects who developed significant IgG titers [18]. However, it has also been shown that immunization with AN-1972 could completely remove amyloid plaques by postmortem assessment in patients still having end-stage dementia symptoms before death [22]. This could be due to the fact that mild-to moderate disease stage is already too late for a diseasemodifying effect of $\mathrm{A} \beta$-plaque removal, but this also calls attention to the role of $\mathrm{A} \beta$ in $\mathrm{AD}$ pathogenesis. Indeed, whether $\mathrm{A} \beta$ is more pathognomonic than pathogenetic is much argued, and so is the therapeutic role of $\mathrm{A} \beta$ removal [23].

The group of drugs targeting tau-protein is currently smaller than anti-A $\beta$ strategies, and includes inhibitors of tau phosphorylation and tau antiaggregants. Lithium and valproate belong to the first category, but so far RCTs using these drugs in AD subjects yielded negative results [24,25]. Among tau antiaggregants, methylthioninium-chloride (methylene blue, MTC) has been tested in patients with $\mathrm{AD}$, with some encouraging results [26]. MTC also shows antioxidant properties and improves mitochondria metabolism, by increasing levels of cytochrome c oxidase (complex IV), heme synthesis, and mitochondrial oxygen consumption. All these events have a potential neuroprotective activity in AD [27].

Overall, striking results in terms of disease-modifying drugs in $\mathrm{AD}$ have not been provided yet. Negative or weak results of many RCTs could be due to theoretical problems, which warrants a critical revaluation of mechanisms involved in AD pathogenesis and methodological issues related to RCTs design. In the latter, it is worth to consider that RCTs usually involve subjects with mild-to-moderate AD. This could be a too advanced disease stage to obtain significant restoring of synaptic and neuronal function. Furthermore, the clinical diagnosis of probable AD often includes a neuropathologically heterogeneous group [28]. This is especially true in advanced age and can influence the ability to detect a disease-modifying effect of a drug considering that RCTs outcomes are usually clinical scales. The development of new diagnostic criteria for $\mathrm{AD}$ [29], which implement the use of biomarkers (cerebrospinal fluid $\mathrm{A} \beta$, tau and phospho-tau; morphological and functional neuroimaging) that can be used in RCTs, may provide the opportunity to select a more homogeneous group of subjects and to measure diseasemodifying effects of a drug.

\section{AD AND MITOCHONDRIA}

In addition to the current strategies of $\mathrm{AD}$ drug development discussed above, we need to consider other alternatives in order to find treatments that either prevent or halt the degeneration of neurons in AD brain. Here we focus on mitochondria as targets for AD therapy and discuss some examples of drugs in development having direct or indirect effects on mitochondrial function.

Neurons are dependent on aerobic oxidative phosphorylation for their energy needs and mitochondria are therefore essential for neuronal function. Mitochondria are abundant in presynaptic nerve terminals where they provide energy for sustained neurotransmittor release. Mitochondrial damage may lead to the release of death factors (e.g., cytochrome c, Omi/HtrA2, Smac/Diablo) resulting in apoptosis, which can be triggered locally in synapses [30]. Dysfunctional mitochondria also lead to decreased ATP production and impaired calcium buffering capacity. No correlation has been established between the number of plaques and the cog- 
nitive performance in $\mathrm{AD}$ patients. Instead, synaptic failure and the intracellular production of $\mathrm{A} \beta$ appear to correlate well with early cognitive dysfunction in $\mathrm{AD}$ patients [31]. It is therefore tempting to speculate that synaptic failure may be caused, at least partially, by loss of mitochondrial function induced by $\mathrm{A} \beta$, for example. Indeed, it is well established that mitochondrial dysfunction is associated with neurodegenerative disorders including $\mathrm{AD}$. In the early stages of $\mathrm{AD}$, there is a decrease in the number of mitochondria in vulnerable neurons [32], brain glucose metabolism is decreased [33], and the activities of both tricarboxylic acid cycle enzymes [34] and cytochrome c oxidase are reduced [35-38]. Recently it was also shown that the levels of mitochondrial fission/fusion proteins are altered and that mitochondria are redistributed away from axons in pyramidal neurons of AD brain [39]. Because of the central role of mitochondria for neuronal survival, the development of therapeutic strategies to protect mitochondria and preserve mitochondrial functions in $\mathrm{AD}$ is important.

\section{Impaired glucose uptake and insulin resistance}

Neurons are unable to store glucose and are therefore dependent on the transport of glucose from the periphery across the blood-brain-barrier (BBB). This transport is insulin-dependent and glucose uptake by neurons is mediated by glucose transporters GLUT1 and GLUT3. As mentioned above, there is a reduction of glucose metabolism in the cerebral cortex, detected by ${ }^{18}$ F-2-deoxy-2-fluoro-D-glucose (FDG) positron emission tomography (PET), in early stage AD [4042]. The reduced utilization of glucose either suggests that cerebral blood flow is reduced [43], insulinsignaling is deficient $[44,45]$, glucose transport mechanisms are impaired [46-49], or that enzymes breaking down glucose are dysfunctional [50,51]. Interestingly, there is a well established link between AD and type II diabetes mellitus [15]. Individuals with type II diabetes and borderline diabetes have an increased risk of developing $\mathrm{AD}[52,53]$. Insulin can pass the $\mathrm{BBB}$ and insulin receptors are expressed in brain areas important for memory formation, e.g., hippocampus and medial temporal cortex. The expression of these insulin receptors is decreased in $\mathrm{AD}$, an indication of insulin resistance. It appears that functional insulin signaling is important both for memory formation and for the transport of glucose into the brain across BBB. PPAR $\gamma$ agonists (e.g., rosiglitazone and pioglitazone) could be beneficial in AD because of their influence on insulin levels and action, lipid metabolism, and inflammation [15], but results from large Phase III RCTs have either not been published or reported as negative [54]. Moreover, the FDA recently warned about possible cardiac risks associated with the use of rosiglitazone [55]. Small clinical tests with administration of intranasal insulin administration are ongoing [56]. Insulin-like peptides reaches the brain via extracellular pathways within 15 min after administration. Patients with early AD or MCI receiving intranasal insulin showed improved working memory, attention and functional status in a 3-week, randomized, double-blind, placebo-controlled pilot study [57]. The SNIFF-120 study is a Phase II RCT testing effects of nasal insulin on cognition, cerebral glucose metabolism, cerebrospinal fluid and plasma levels of $\mathrm{A} \beta$ in subjects with MCI or $\mathrm{AD}$ [18].

\section{Oxidative stress}

The brain, although representing only $\sim 2 \%$ of the body mass, is responsible for $\sim 20 \%$ of the total $\mathrm{O}_{2}$ consumption [58]. This is because neurons has a limited glycolytic capacity and are highly dependent on oxidative phosphorylation for ATP production, a process requiring $\mathrm{O}_{2}$. In this process, electrons are transported through protein complexes of the respiratory chain located in the mitochondrial inner membrane. During electron transport, protons are pumped out from the matrix into the inter membrane space resulting in a negative membrane potential $\left(\psi_{\text {mit }}\right)$ across the inner membrane. At the end of the respiratory chain, $\mathrm{O}_{2}$ is reduced to $\mathrm{H}_{2} \mathrm{O}$ and ATP formed using the energy built up in the $\psi_{\text {mit }}$ [59]. During electron transport there is a leakage of electrons from the enzyme complexes and reactive oxygen species (ROS) are produced when electrons react with $\mathrm{O}_{2}$. Reactive nitrogen species (RNS) are other free radicals normally produced in the body. ROS and RNS cause oxidative and nitrosative damage to proteins, RNA and DNA as well as peroxidation of lipids, in particular phospholipids in biological membranes [60,61]. Enzymatic (glutathione peroxidase, Mn- and CuZn-superoxide dismutases) and non-enzymatic (vitamin $\mathrm{E}$, vitamin $\mathrm{C}$, uric acid) antioxidants, as well as repair systems are physiologically present to counteract free radical damage. However, if the generation of ROS/RNS exceeds degradation, the redox homeostasis is altered resulting in oxidative stress and nitrosative stress. Increased protein-, RNA, DNA- and lipid oxidative/nitrosative damage have all been detected in AD tissue, suggesting increased oxidative and nitrosative stress in AD [61,62]. These 
data from human samples are supported by results from transgenic mouse models overexpressing mutated A $\beta$ PP. However, clinical studies where patients receive vitamin $\mathrm{E}$ have not shown conclusive evidence that antioxidants have a positive effect on AD patients as discussed below. Still, aging is the major risk factor for $\mathrm{AD}$ and it is widely accepted that an elevation in oxidative damage is one of the most ubiquitous alterations observed in aging cells and tissues. Therefore, it is likely that increased oxidative damage contributes to the development of age-related disorders, including AD.

\section{$A \beta$}

Several lines of evidence point towards a role for $\mathrm{A} \beta$ toxicity in the mitochondrial dysfunction found in $\mathrm{AD}$. We and others have shown that $\mathrm{A} \beta$ accumulates in mitochondria in postmortem $\mathrm{AD}$ brain, living patients with cortical plaques, and $\operatorname{Tg} \mathrm{A} \beta \mathrm{PP}$ mice [63-66]. In $\operatorname{Tg} \mathrm{A} \beta \mathrm{PP}$ mice, mitochondrial $\mathrm{A} \beta$ accumulation occurs prior to plaque formation, indicating that this is an early event in disease pathogenesis [63]. In vitro studies with isolated mitochondria suggest that $\mathrm{A} \beta_{1-42}$ inhibits cytochrome c oxidase activity in a copper-dependent manner [67]. Furthermore, mitochondrial $\mathrm{A} \beta$-binding alcohol dehydrogenase (ABAD) has been found to be upregulated in neurons from $\mathrm{AD}$ patients [64] and $\mathrm{A} \beta$ has been shown to interact with $\mathrm{ABAD}$ resulting in free radical production and neuronal apoptosis. ABAD was identified as an $\mathrm{A} \beta$-binding protein in a yeast two-hybrid screen [64], is localized to the mitochondrial matrix, and has an essential physiological role in mitochondria. ABAD-A $\beta$ complexes were detected in $\mathrm{AD}$ brain and in $\mathrm{Tg}$ mutant $\mathrm{A} \beta \mathrm{PP} / \mathrm{ABAD}$ ( $\mathrm{Tg}$ $\mathrm{mA} \beta \mathrm{PP} / \mathrm{ABAD})$ mice. Cortical neurons cultured from $\mathrm{Tg} \mathrm{mA} \beta \mathrm{PP} / \mathrm{ABAD}$ mice show increased production of ROS and decreased mitochondrial membrane potential, ATP levels and activity of respiratory chain complex IV. Consistently, these neurons displayed DNAfragmentation and caspase- 3 activity resulting in cell death by day 5-6 in culture [68]. ABAD uses NAD ${ }^{+}$ and/or $\mathrm{NADH}$ as its cofactor and catalyzes the reversible oxidation and/or reduction of alcohol group in its substrates [69]. The crystal structure of ABAD$\mathrm{A} \beta$ complexes has been determined and shows that the $\mathrm{NAD}^{+}$binding pocket is distorted, hindering $\mathrm{NAD}^{+}$ from binding to ABAD in the presence of $\mathrm{A} \beta[64,69]$. Thus $\mathrm{A} \beta$ blocks ABAD activity causing mitochondrial dysfunction and ultimately cell death. Two stretches of $\mathrm{ABAD}$ residues in the $\mathrm{L}_{D}$ loop region (amino acids 95-113) have been shown to be important for $\mathrm{A} \beta$ binding. Cell permeable peptides (amino acids 92-120, ABAD-DP) protected cells from cytochrome c release, DNA fragmentation, and attenuated cell death in neuronal cultures. ABAD-DP also blocked the production of ROS both in cultured neurons and in mouse brain tissue. Small-molecule inhibitors of the ABAD-A $\beta$ interaction belonging to a class of benzothiazole ureas have been identified [70] and ABAD emerges as a new drug target for $\mathrm{AD}$.

$\mathrm{A} \beta$ has also been shown to specifically interact with cyclophilin D (CypD), a mitochondrial matrix protein that associates with the inner membrane during opening of the mitochondrial permeability transistion pore (mPTP) [71]. Cortical mitochondria from CypD deficient mice are resistant to $\mathrm{A} \beta$ - and calciuminduced mitochondrial swelling and permeability transition. Moreover, Tg mA $\beta$ PP/CypD-null mice had improved learning and memory and synaptic function both in 12 and 24 months old animals [71,72].

Recently, it was shown that Presequence Protease (PreP) is responsible for the degradation of the accumulated $\mathrm{A} \beta$ in mitochondria [73]. PreP was originally found and characterized in Arabidopsis thaliana [74] as a protease degrading targeting peptides that are cleaved off in mitochondria after completed protein import as well as other unstructured peptides up to 65 amino acid residues in length, but not small proteins $[75,76]$. Recombinant hPreP completely degrades both $\mathrm{A} \beta_{40}$ and $\mathrm{A} \beta_{42}$ as well as $\mathrm{A} \beta$ Arctic protein $(42, \mathrm{E} 22 \mathrm{G})$ at unique cleavage sites including several sites in a very hydrophobic $\mathrm{C}$-terminal $\mathrm{A} \beta_{29-42}$ segment that is prone to aggregation. Interestingly, PreP is an organellar functional analogue of the human insulin degrading enzyme (IDE), implicated in AD as it cleaves $\mathrm{A} \beta$ before insoluble amyloid fibers are formed [77-79].

The presence of $\mathrm{A} \beta$ in mitochondria indicates that it is either produced inside mitochondria and/or taken up from the outside. Both A $\beta \mathrm{PP}[80]$ and $\gamma$-secretase complexes [81] have been detected in mitochondria and thus it is possible that $\mathrm{A} \beta$ is produced locally in mitochondria. However, this remains to be proven. $\mathrm{A} \beta \mathrm{PP}$ has been shown to accumulate in $\mathrm{AD}$ brain mitochondria via arrested import leaving a large C-terminal part outside [80]. Under these circumstances $\mathrm{A} \beta \mathrm{PP}$ is stuck in the mitochondrial protein import pore, consisting of the translocases of the outer- (TOM) and inner membrane (TIM), causing impairment of mitochondrial function and eventually cell toxicity. The import of $\mathrm{A} \beta \mathrm{PP}$ is blocked due to an acidic domain at amino acids 220290 leaving the $\mathrm{A} \beta$-region outside the import pore. Re- 
cent data from our laboratory show that the $\mathrm{C}$-terminal part of $\mathrm{A} \beta \mathrm{PP}$ can be inserted into the outer mitochondrial membrane (OMM) and that the mitochondrial $\gamma$ secretase cleaves $\mathrm{A} \beta \mathrm{PP}$ to generate $\mathrm{A} \beta \mathrm{PP}$ intracellular domain (AICD) which was detected in the inter membrane space (Pavlov et al., unpublished data). Thus it is possible that $\mathrm{A} \beta$ is also produced in the mitochondria and then either released on the outside or inside of the OMM. A $\beta$ coming from the outside of mitochondria (either produced by mitochondria or transported to mitochondria via vesicles [82] or mitochondria-associated membranes [83]) can then be taken up by mitochondria and cause toxicity. Therefore we also investigated the mechanisms of $\mathrm{A} \beta$ uptake using isolated mitochondria treated with $A \beta$ in the absence or presence of antibodies or inhibitors directed to various mitochondrial translocases and pores [66]. The uptake of $\mathrm{A} \beta$ was not affected by the presence of antibodies directed towards the voltage-dependent anion channel (VDAC) nor in the presence of Cyclosporine A which is an inhibitor of the mPTP. Interestingly, import of both $\mathrm{A} \beta_{1-40}$ and $\mathrm{A} \beta_{1-42}$ was prevented when import competent mitochondria were pre-incubated with antibodies directed toward proteins of the TOM complex, i.e., Tom20, Tom40, and Tom70. A $\beta$ import was not affected by the addition of valinomycin, an ionophore which cause depolarization of the mitochondrial inner membrane, indicating that the $\mathrm{A} \beta$ import was not dependent on the $\psi_{\text {mit }}$. After import, $\mathrm{A} \beta$ was mostly localized to mitochondrial cristae and associated with the inner membrane fraction. It was earlier reported that $\mathrm{A} \beta$ colocalizes with the mitochondrial matrix protein Hsp60 in mouse and human samples [63]. One explanation to this discrepancy might be that in our in vitro assay, we studied $\mathrm{A} \beta$ localization after 30 min of import, whereas Caspersen and colleagues report data from postmortem $\mathrm{AD}$ brains and 8-months-old transgenic $\mathrm{A} \beta \mathrm{PP}$ mice. However, our data from brain biopsies obtained from living subjects, displaying $\mathrm{A} \beta$ aggregates in the neuropil, show $\mathrm{A} \beta$ immuno-gold labeling in association with mitochondrial inner membranes [66]. This said, we cannot exclude the possibility that $\mathrm{A} \beta$ can be released or escapes from the membrane and also localizes to the matrix. In summary, these data show that $\mathrm{A} \beta$ is imported via the TOM complex where Tom 20 and Tom70 are receptors and Tom40 forms a pore in the OMM.

Very recently, Roses and colleagues reported that a polymorphic poly-T variant in the TOMM40 gene can be used to estimate the age of sporadic AD onset for $A P O E \varepsilon 3$ carriers. $A P O E \varepsilon 3 / 4$ carriers with long
poly-T repeats linked to $A P O E \varepsilon 3$ had an age of onset 7 years earlier as compared to individuals with shorter repeats [84]. TOMM4O and APOE genes are separated by only $\sim 2 \mathrm{~kb}$ on chromosome 19 . The effect of different poly-T lengths on the Tom 40 protein are presently unknown but it is possible that it results in exon skipping as is the case for the CFTR gene with a role in cystic fibrosis. This would result in a modified protein with potentially altered function which could for example influence protein import into mitochondria. The poly-T stretch could also influence $A P O E$ transcription. The interaction between ApoE fragments and mitochondria [85] might also be influenced by the TOMM40 polymorphism. These possibilities require further investigation and would certainly link mitochondria even tighter to $\mathrm{AD}$ pathogenesis.

\section{POTENTIAL AD DRUGS AFFECTING MITOCHONDRIAL FUNCTION}

\section{Antioxidants}

Oxidative stress and nitrosative stress are considered important mediators in AD onset and progression [86, 87]. Increased levels of different biomarkers of oxidative and nitrosative stress damage have been found in diseased brain regions and peripheral tissues of patients with $\mathrm{AD}$, and similar findings were reported in subjects with mild cognitive impairment (MCI) [61]. Since individuals with MCI are at increased risk of developing dementia [88], the evidence of oxidative stress and nitrosative stress in subjects with MCI suggests that these as early events in cognitive decline.

Some studies report reduced concentrations of plasma antioxidant micronutrients in subjects with $\mathrm{AD}$ and MCI [89,90], suggesting an inadequate antioxidant activity in these disorders, and antioxidants have received great attention as a possible means to prevent and treat AD. Within this category, vitamin $\mathrm{E}$ is the major lipid-soluble, chain-breaking, non-enzymatic antioxidant in the body, with a key role in protecting cellular membranes. This could be crucial in mitochondria, which are both main source and elective target of free radicals. $\alpha$-tocopherol is the vitamin $\mathrm{E}$ form with the highest bioavailability in humans, and it is the most investigated in AD. Double transgenic mice model of AD (Ttpa ${ }^{-/-}$A $\beta$ PPsw), knockout for the $\alpha$ tocopherol transfer protein ( $\alpha$-TTP) and thus with systemic $\alpha$-tocopherol deficiency, showed increased $\mathrm{A} \beta$ brain deposits and early and severe cognitive dysfunc- 
tion, all events being improved by $\alpha$-tocopherol supplementation [91]. Mito- $\mathrm{E}_{2}$, generated by conjugating $\alpha$ tocopherol to the lipophylic cation triphenylphosphonium $(\mathrm{TPP}+)$, is a mitochondria-targeted antioxidant that is selectively enriched in mitochondria. Mito- $\mathrm{E}_{2}$ can efficiently distribute in peripheral tissues, including CNS in mice [92], and it has been shown to protect from oxidative damage [93] and influence $\mathrm{Ca}^{2+}$ signaling in cellular models [94].

The use of $\alpha$-tocopherol has been evaluated in several neurological disorders associated with increased oxidative stress, such as AD, Parkinson's disease, and amyotrophic lateral sclerosis [95]. Results from RCTs on $\alpha$-tocopherol in AD and MCI therapy are conflicting [96], and methodological problems could explain, at least in part, this inconsistency. Short duration of the supplementation and too advanced disease stage have been used to explain the negative results, which could be also due to the choice of the wrong dosage and/or the use of only $\alpha$-tocopherol. Indeed vitamin $\mathrm{E}$ is a family of eight natural compounds (four tocopherols and four tocotrienols), all acting as antioxidants [97], and each form shows unique biological functions (i.e., anti-inflammatory activity and modulation of different signaling pathways) that can contribute to neuroprotection [98]. Epidemiological studies suggest that the protective effect of vitamin $\mathrm{E}$ against $\mathrm{AD}$ can be due to the contribution of different forms [99,100], while in RCTs only $\alpha$-tocopherol has been used, often in high doses. Intake of high doses of $\alpha$-tocopherol can decrease the bioavailability of the other vitamin E forms [101, 102] and has been associated with an increased mortality risk [103], suggesting that a balanced combination of vitamin $\mathrm{E}$ forms is important for neuroprotection, and that supplement composition needs to be refined. Another important issue worth consideration in supplementation studies is the importance of assessing biomarkers (i.e., antioxidants, markers of oxidative stress/nitrosative stress) before and after the intervention, in order to identify subjects who could benefit from the supplementation and to monitor compliance and response to treatment.

Coenzyme $\mathrm{Q}_{10}$ (ubiquinone) is another antioxidant investigated in neurodegenerative diseases. Coenzyme $\mathrm{Q}_{10}$, synthesized by the human body, is a cofactor in the mitochondrial electron transport chain and is thus essential for ATP production. In a mouse model of AD, coenzyme $\mathrm{Q}_{10}$ supplementation reduced $\mathrm{A} \beta_{42}$ levels in the cortex and decreased levels of markers of oxidative stress [104]. Phase III RCTs with Coenzyme $\mathrm{Q}_{10}$ are ongoing in subjects with Huntington's disease and
Parkinson's disease [18], while currently there are no studies on AD subjects.

MitoQ $_{10}$ is the $\mathrm{TTP}^{+}$conjugated form of coenzyme $\mathrm{Q}_{10}$, that is selectively accumulated in the mitochondrial matrix [94]. MitoQ ${ }_{10}$ has been shown to reach peripheral tissues and to protect against oxidative damage in animal models [93]. MitoQ 10 affects $\mathrm{Ca}^{2+}$ homeostasis in cellular models but, as with Mito- $\mathrm{E}_{2}$, this effect seems to be mediated mainly by $\mathrm{TTP}^{+}$[94]. How this can influence the effect of the antioxidants on mitochondria is not yet clear. Thus, when using complex molecules it is essential to understand the interaction between mitochondria and shuttle compounds, such as $\mathrm{TPP}^{+}$, which allows selective accumulation of the active drug but could independently influence mitochondrial components.

\section{Dimebon (latrepirdine)}

Dimebon was originally approved in the former Soviet Union as a non-selective antihistamine for skin allergy and allergic rhinitis [105], but was withdrawn from the market with the advent of more selective treatments. Dimebon attracted renewed interest due to findings suggesting a neuroprotective effect [106-108]. In a Phase II AD trial, Dimebon treatment was associated with benefits on cognition, global function, activities of daily living, and behavior [109]. Several Phase III clinical trials are ongoing for both AD and Huntington's disease [18]. The first reported data from the CONNECTION study, where patients received Dimebon or placebo for six months, did not meet primary or secondary efficacy endpoints. However, it should be noted that neither group was significantly changed from baseline. Dimebon exhibits a rich pharmacological profile and binds to histamine-, adrenergic-, dopamine-, and serotonin-receptors $[108,110]$. It is known to be a weak inhibitor of: acetylcholinesterase $\left(\mathrm{IC}_{50}=8-\right.$ $42 \mu \mathrm{M})$ [107], N-methyl-D-aspartate (NMDA) receptors $\left(\mathrm{IC}_{50}=10 \mu \mathrm{M}\right)[108,111]$, and voltage-gated calcium channels $\left(\mathrm{IC}_{50}=50 \mu \mathrm{M}\right)[108,112]$. In addition, $\mu \mathrm{M}$ concentrations of Dimebon have previously been shown to protect against neuronal cell death induced by $\mathrm{A} \beta_{25-35}$ [107] and to modulate the mPTP (10$200 \mu \mathrm{M})$ [113]. In a recent study from our laboratory [114] we show that nM concentrations of Dimebon (1 to 5 days incubation) results in an increase of $\psi_{\text {mit }}$ (hyperpolarization) and cellular ATP levels both in mouse cortical neurons and human neuroblastoma cells. Moreover, Dimebon pretreatment made cells more resistant to depolarization of $\psi_{\text {mit }}$-induced by high intracellular 
calcium concentrations. Cells were also protected from undergoing cell death induced either by calcium stress or withdrawal of growth factors. Our study suggests that Dimebon directly or indirectly affects mitochondria making cells more resistant to cell death stimuli.

In another study of the mode of action of Dimebon, the effect on intracellular protein inclusions was investigated in a cellular model of TDP-43 proteinopathy. Yamasita and colleagues showed that $\mu \mathrm{M}$ concentrations of Dimebon (3 days incubation) decreased the number of TDP-43 aggregates in human neuroblastoma SH-SY5Y cells expressing mutant TDP43 [115]. This study suggests that Dimebon possess anti-oligomerization properties. Additionally, Steele and colleagues have studied the effect of Dimebon on $\mathrm{A} \beta$ secretion in three different model systems [116]. In mouse neuroblastoma $\mathrm{N} 2 \mathrm{a}$ cells overexpressing $\mathrm{hA} \beta \mathrm{PP}_{\mathrm{swe}}$, a $6 \mathrm{~h}$ treatment with Dimebon (500 pM$5 \mu \mathrm{M})$ resulted in an increase in total extracellular $\mathrm{A} \beta$. No significant changes in $\mathrm{A} \beta_{x-42} / \mathrm{A} \beta_{x-40}$ were observed. The release of $\mathrm{A} \beta$ from synptoneurosomes isolated from tgCRND8 mice ( $\mathrm{hA} \beta \mathrm{PP}_{\text {swe/ind }}$ ) was studied after short time (1-10 min) incubation with Dimebon $(1$ or $10 \mu \mathrm{M})$. In this model system, the secretion of $\mathrm{A} \beta_{x-42}$ was elevated in Dimebon treated samples. Finally, a $41 \%$ increase in $\mathrm{A} \beta_{x-40}$ levels was detected in the interstitial fluid from the brains of $\mathrm{Tg} 2576$ mice $\left(\mathrm{hA} \beta \mathrm{PP}_{\text {swe }}\right)$ analyzed $10 \mathrm{~h}$ following injection of $3.5 \mathrm{mg} / \mathrm{kg}$ Dimebon. The Dimebon stimulated A $\beta$ secretion could be caused by changes in neurotransmission, coupled with synaptic activity, or by effects on $\mathrm{A} \beta$ oligomerization. A mechanistic link between the effects observed in cell- and animal models could be that Dimebon simultaneously strengthen mitochondrial functions and increases $\mathrm{A} \beta$ secretion from neurons and brain. This is at present highly speculative and needs further investigation.

\section{CONCLUSIONS}

Drugs available for AD include acetylcholinesterase inhibitors and memantine both targeting neurotransmission. Current developments in therapies for AD are largely based on anti-amyloid strategies and it remains to be shown that such approaches will be diseasemodifying or improve cognitive functions. One alternative strategy is to target mitochondria which are central for neuronal survival and shown to have impaired function in neurodegenerative disorders. To specifically target an organelle with double membranes is a chal- lenge since the compound has to pass through the $\mathrm{BBB}$, cell membrane, and mitochondrial membrane. For the last step, one can take advantage of the fact that the matrix of mitochondria is negatively charged and that positively charged molecules will accumulate inside mitochondria, e.g., MitoQ 10 and Mito-E 2 . Lipophilic cations may accumulate 100- to 1000-fold in mitochondria. This strategy has so far been tested with antioxidants but other small molecules that, for example, block $\mathrm{A} \beta$-ABAD interactions or mitochondrial $\mathrm{A} \beta$-uptake, could also be targeted to mitochondria using the same principle. Preservation of proper mitochondrial function is central for the maintenance of synaptic activity and neuronal function in general. Since mitochondria are affected in early stage $\mathrm{AD}$, strategies to develop drugs that protect mitochondria from damage are worth pursuing.

\section{DISCLOSURE STATEMENTS}

Authors' disclosures available online (http://www.jalz.com/disclosures/view.php?id=399).

\section{REFERENCES}

[1] Bolognesi ML, Matera R, Minarini A, Rosini M, Melchiorre C (2009) Alzheimer's disease: new approaches to drug discovery. Curr Opin Chem Biol 13, 303-308.

[2] Moreira PI, Zhu X, Wang X, Lee HG, Nunomura A, Petersen RB, Perry G, Smith MA Mitochondria: a therapeutic target in neurodegeneration. Biochim Biophys Acta 1802, 212-220.

[3] Winblad B (2009) Donepezil in severe Alzheimer's disease. Am J Alzheimers Dis Other Demen 24, 185-192.

[4] Birks J (2006) Cholinesterase inhibitors for Alzheimer's disease. Cochrane Database Syst Rev, CD005593.

[5] Nordberg A (2006) Mechanisms behind the neuroprotective actions of cholinesterase inhibitors in Alzheimer disease. Alzheimer Dis Assoc Disord 20, S12-18.

[6] Wenk GL, Parsons CG, Danysz W (2006) Potential role of N-methyl-D-aspartate receptors as executors of neurodegeneration resulting from diverse insults: focus on memantine. Behav Pharmacol 17, 411-424.

[7] Winblad B, Jones RW, Wirth Y, Stoffler A, Mobius HJ (2007) Memantine in moderate to severe Alzheimer's disease: a meta-analysis of randomised clinical trials. Dement Geriatr Cogn Disord 24, 20-27.

[8] Mecocci P, Bladstrom A, Stender K (2009) Effects of memantine on cognition in patients with moderate to severe Alzheimer's disease: post-hoc analyses of ADAS-cog and SIB total and single-item scores from six randomized, double-blind, placebo-controlled studies. Int J Geriatr Psychiatry 24, 532-538.

[9] Tariot PN, Farlow MR, Grossberg GT, Graham SM, McDonald S, Gergel I (2004) Memantine treatment in patients with moderate to severe Alzheimer disease already receiving donepezil: a randomized controlled trial. JAMA 291, 317324. 
[10] Atri A, Shaughnessy LW, Locascio JJ, Growdon JH (2008) Long-term course and effectiveness of combination therapy in Alzheimer disease. Alzheimer Dis Assoc Disord 22, 209221.

[11] Pei JJ, Sjogren M, Winblad B (2008) Neurofibrillary degeneration in Alzheimer's disease: from molecular mechanisms to identification of drug targets. Curr Opin Psychiatry 21, 555-561.

[12] Wu HM, Tzeng NS, Qian L, Wei SJ, Hu X, Chen SH, Rawls SM, Flood P, Hong JS, Lu RB (2009) Novel neuroprotective mechanisms of memantine: increase in neurotrophic factor release from astroglia and anti-inflammation by preventing microglial activation. Neuropsychopharmacology 34, 23442357.

[13] Mudher A, Lovestone S (2002) Alzheimer's disease-do tauists and baptists finally shake hands? Trends Neurosci $\mathbf{2 5}$, 22-26.

[14] Kimberly WT, LaVoie MJ, Ostaszewski BL, Ye W, Wolfe MS, Selkoe DJ (2003) Gamma-secretase is a membrane protein complex comprised of presenilin, nicastrin, Aph-1, and Pen-2. Proc Natl Acad Sci U S A 100, 6382-6387.

[15] Landreth G, Jiang Q, Mandrekar S, Heneka M (2008) PPARgamma agonists as therapeutics for the treatment of Alzheimer's disease. Neurotherapeutics 5, 481-489.

[16] Bateman RJ, Siemers ER, Mawuenyega KG, Wen G, Browning KR, Sigurdson WC, Yarasheski KE, Friedrich SW, Demattos RB, May PC, Paul SM, Holtzman DM (2009) A gamma-secretase inhibitor decreases amyloid-beta production in the central nervous system. Ann Neurol 66, 48-54.

[17] Henley DB, May PC, Dean RA, Siemers ER (2009) Development of semagacestat (LY450139), a functional gammasecretase inhibitor, for the treatment of Alzheimer's disease. Expert Opin Pharmacother 10, 1657-1664.

[18] Clinicaltrials.gov, Effect

LY450139 on the long term progression of Alzheimer's disease, http://clinicaltrials.gov/ct2/show/NCT00594568, Accessed May 3, 2010.

[19] Adlard PA, Cherny RA, Finkelstein DI, Gautier E, Robb E, Cortes M, Volitakis I, Liu X, Smith JP, Perez K, Laughton K, Li QX, Charman SA, Nicolazzo JA, Wilkins S, Deleva K, Lynch T, Kok G, Ritchie CW, Tanzi RE, Cappai R, Masters CL, Barnham KJ, Bush AI (2008) Rapid restoration of cognition in Alzheimer's transgenic mice with 8-hydroxy quinoline analogs is associated with decreased interstitial Abeta. Neuron 59, 43-55.

[20] Mandel SA, Amit T, Kalfon L, Reznichenko L, Weinreb O, Youdim MB (2008) Cell signaling pathways and iron chelation in the neurorestorative activity of green tea polyphenols: special reference to epigallocatechin gallate (EGCG). J Alzheimers Dis 15, 211-222.

[21] Gilman S, Koller M, Black RS, Jenkins L, Griffith SG, Fox NC, Eisner L, Kirby L, Rovira MB, Forette F, Orgogozo JM (2005) Clinical effects of Abeta immunization (AN1792) in patients with AD in an interrupted trial. Neurology 64, 1553-1562.

[22] Holmes C, Boche D, Wilkinson D, Yadegarfar G, Hopkins V, Bayer A, Jones RW, Bullock R, Love S, Neal JW, Zotova E, Nicoll JA (2008) Long-term effects of Abeta42 immunisation in Alzheimer's disease: follow-up of a randomised, placebocontrolled phase I trial. Lancet 372, 216-223.

[23] Shah RS, Lee HG, Xiongwei Z, Perry G, Smith MA, Castellani RJ (2008) Current approaches in the treatment of Alzheimer's disease. Biomed Pharmacother 62, 199-207.
[24] Hampel H, Ewers M, Burger K, Annas P, Mortberg A, Bogstedt A, Frolich L, Schroder J, Schonknecht P, Riepe MW, Kraft I, Gasser T, Leyhe T, Moller HJ, Kurz A, Basun H (2009) Lithium trial in Alzheimer's disease: a randomized, single-blind, placebo-controlled, multicenter 10-week study. $J$ Clin Psychiatry 70, 922-931.

[25] Tariot PN, Aisen P, Cummings J, Jakimovich L, Schneider L, Thomas R, Becerra L, Loy R (2009) The ADCS valproate neuroprotection trial: Primary efficacy and safety results. Alzheimers Dement 5 (Suppl), P84-P85.

[26] Gura T (2008) Hope in Alzheimer's fight emerges from unexpected places. Nat Med 14, 894.

[27] Atamna H, Nguyen A, Schultz C, Boyle K, Newberry J, Kato H, Ames BN (2008) Methylene blue delays cellular senescence and enhances key mitochondrial biochemical pathways. FASEB J 22, 703-712.

[28] Schneider JA, Arvanitakis Z, Leurgans SE, Bennett DA (2009) The neuropathology of probable Alzheimer disease and mild cognitive impairment. Ann Neurol 66, 200-208.

[29] Dubois B, Feldman HH, Jacova C, Dekosky ST, BarbergerGateau P, Cummings J, Delacourte A, Galasko D, Gauthier S, Jicha G, Meguro K, O'Brien J, Pasquier F, Robert P, Rossor M, Salloway S, Stern Y, Visser PJ, Scheltens P (2007) Research criteria for the diagnosis of Alzheimer's disease: revising the NINCDS-ADRDA criteria. Lancet Neurol 6, 734746.

[30] Mattson MP, Gary DS, Chan SL, Duan W (2001) Perturbed endoplasmic reticulum function, synaptic apoptosis and the pathogenesis of Alzheimer's disease. Biochem Soc Symp, 151-162.

[31] Wilson CA, Doms RW, Lee VM (1999) Intracellular APP processing and A beta production in Alzheimer disease. $J$ Neuropathol Exp Neurol 58, 787-794.

[32] Hirai K, Aliev G, Nunomura A, Fujioka H, Russell RL, Atwood CS, Johnson AB, Kress Y, Vinters HV, Tabaton M, Shimohama S, Cash AD, Siedlak SL, Harris PL, Jones PK, Petersen RB, Perry G, Smith MA (2001) Mitochondrial abnormalities in Alzheimer's disease. J Neurosci 21, 3017-3023.

[33] Mosconi L (2005) Brain glucose metabolism in the early and specific diagnosis of Alzheimer's disease. FDG-PET studies in MCI and AD. Eur J Nucl Med Mol Imaging 32, 486-510.

[34] Bubber P, Haroutunian V, Fisch G, Blass JP, Gibson GE (2005) Mitochondrial abnormalities in Alzheimer brain: mechanistic implications. Ann Neurol 57, 695-703.

[35] Parker WD, Jr., Filley CM, Parks JK (1990) Cytochrome oxidase deficiency in Alzheimer's disease. Neurology 40, 1302-1303.

[36] Parker WD, Jr., Parks JK (1995) Cytochrome c oxidase in Alzheimer's disease brain: purification and characterization. Neurology 45, 482-486.

[37] Cardoso SM, Santana I, Swerdlow RH, Oliveira CR (2004) Mitochondria dysfunction of Alzheimer's disease cybrids enhances Abeta toxicity. J Neurochem 89, 1417-1426.

[38] Kish SJ, Bergeron C, Rajput A, Dozic S, Mastrogiacomo F, Chang LJ, Wilson JM, DiStefano LM, Nobrega JN (1992) Brain cytochrome oxidase in Alzheimer's disease. $\mathrm{J} \mathrm{Neu}$ rochem 59, 776-779.

[39] Wang X, Su B, Lee HG, Li X, Perry G, Smith MA, Zhu X (2009) Impaired balance of mitochondrial fission and fusion in Alzheimer's disease. J Neurosci 29, 9090-9103.

[40] Jagust WJ, Seab JP, Huesman RH, Valk PE, Mathis CA, Reed BR, Coxson PG, Budinger TF (1991) Diminished glucose transport in Alzheimer's disease: dynamic PET studies. $J$ Cereb Blood Flow Metab 11, 323-330. 
[41] Smith GS, de Leon MJ, George AE, Kluger A, Volkow ND, McRae T, Golomb J, Ferris SH, Reisberg B, Ciaravino J, et al. (1992) Topography of cross-sectional and Longitudinal glucose metabolic deficits in Alzheimer's disease. Pathophysiologic implications. Arch Neurol 49, 1142-1150.

[42] Alexander GE, Chen K, Pietrini P, Rapoport SI, Reiman EM (2002) Longitudinal PET Evaluation of Cerebral Metabolic Decline in Dementia: A Potential Outcome Measure in Alzheimer's Disease Treatment Studies. Am J Psychiatry 159, 738-745.

[43] de la Torre JC (2004) Alzheimer's disease is a vasocognopathy: a new term to describe its nature. Neurol Res 26, 517524.

[44] de la Monte SM, Wands JR (2005) Review of insulin and insulin-like growth factor expression, signaling, and malfunction in the central nervous system: relevance to Alzheimer's disease. J Alzheimers Dis 7, 45-61.

[45] Zhu X, Perry G, Smith MA (2005) Insulin signaling, diabetes mellitus and risk of Alzheimer disease. J Alzheimers Dis 7, 81-84.

[46] Kalaria RN, Harik SI (1989) Reduced glucose transporter at the blood-brain barrier and in cerebral cortex in Alzheimer disease. J Neurochem 53, 1083-1088.

[47] Simpson IA, Chundu KR, Davies-Hill T, Honer WG, Davies P (1994) Decreased concentrations of GLUT1 and GLUT3 glucose transporters in the brains of patients with Alzheimer's disease. Ann Neurol 35, 546-551.

[48] Mooradian AD, Chung HC, Shah GN (1997) GLUT-1 expression in the cerebra of patients with Alzheimer's disease. Neurobiol Aging 18, 469-474.

[49] Vannucci SJ, Clark RR, Koehler-Stec E, Li K, Smith CB, Davies P, Maher F, Simpson IA (1998) Glucose transporter expression in brain: relationship to cerebral glucose utilization. Dev Neurosci 20, 369-379.

[50] Sorbi S, Bird ED, Blass JP (1983) Decreased pyruvate dehydrogenase complex activity in Huntington and Alzheimer brain. Ann Neurol 13, 72-78.

[51] Mastrogiacomo F, Bergeron C, Kish SJ (1993) Brain alphaketoglutarate dehydrogenase complex activity in Alzheimer's disease. J Neurochem 61, 2007-2014.

[52] Xu W, Qiu C, Gatz M, Pedersen NL, Johansson B, Fratiglioni $\mathrm{L}$ (2009) Mid- and late-life diabetes in relation to the risk of dementia: a population-based twin study. Diabetes 58, 71-77.

[53] Xu W, Qiu C, Winblad B, Fratiglioni L (2007) The effect of borderline diabetes on the risk of dementia and Alzheimer's disease. Diabetes 56, 211-216.

[54] Gold M, Alderton C, Zvartau-Hind ME, Ritchie S, Saunders A, Craft S, Landreth G, Linnamagi U (2009) Effects of rosiglitazone as monotherapy in APOE4-stratified subjects with mild-to-moderate Alzheimer's disease. Alzheimers Dement 5 (Suppl), P86.

[55] Committee on Finance United States Senate (2010) Staff report on GLAXOSMITHKLINE and the diabetes drug AVANDIA. U.S. Government Printing Office, Washington.

[56] Sabbagh MN (2009) Drug development for Alzheimer's disease: where are we now and where are we headed? Am J Geriatr Pharmacother 7, 167-185.

[57] Reger MA, Watson GS, Green PS, Wilkinson CW, Baker LD, Cholerton B, Fishel MA, Plymate SR, Breitner JC, DeGroodt W, Mehta P, Craft S (2008) Intranasal insulin improves cognition and modulates beta-amyloid in early AD. Neurology 70, 440-448.
[58] Erecinska M, Silver IA (2001) Tissue oxygen tension and brain sensitivity to hypoxia. Respir Physiol 128, 263-276.

[59] Mitchell P, Moyle J (1967) Chemiosmotic hypothesis of oxidative phosphorylation. Nature 213, 137-139.

[60] Szewczyk A, Wojtczak L (2002) Mitochondria as a pharmacological target. Pharmacol Rev 54, 101-127.

[61] Mangialasche F, Polidori MC, Monastero R, Ercolani S, Camarda C, Cecchetti R, Mecocci P (2009) Biomarkers of oxidative and nitrosative damage in Alzheimer's disease and mild cognitive impairment. Ageing Res Rev 8, 285-305.

[62] Pratico D (2008) Evidence of oxidative stress in Alzheimer's disease brain and antioxidant therapy: lights and shadows. Ann N Y Acad Sci 1147, 70-78.

[63] Caspersen C, Wang N, Yao J, Sosunov A, Chen X, Lustbader JW, Xu HW, Stern D, McKhann G, Yan SD (2005) Mitochondrial Abeta: a potential focal point for neuronal metabolic dysfunction in Alzheimer's disease. FASEB J 19, 2040-2041.

[64] Lustbader JW, Cirilli M, Lin C, Xu HW, Takuma K, Wang N, Caspersen C, Chen X, Pollak S, Chaney M, Trinchese F, Liu S, Gunn-Moore F, Lue LF, Walker DG, Kuppusamy P, Zewier ZL, Arancio O, Stern D, Yan SS, Wu H (2004) ABAD directly links Abeta to mitochondrial toxicity in Alzheimer's disease. Science 304, 448-452.

[65] Manczak M, Anekonda TS, Henson E, Park BS, Quinn J, Reddy PH (2006) Mitochondria are a direct site of A beta accumulation in Alzheimer's disease neurons: implications for free radical generation and oxidative damage in disease progression. Hum Mol Genet 15, 1437-1449.

[66] Hansson Petersen CA, Alikhani N, Behbahani H, Wiehager B, Pavlov PF, Alafuzoff I, Leinonen V, Ito A, Winblad B, Glaser E, Ankarcrona M (2008) The amyloid beta-peptide is imported into mitochondria via the TOM import machinery and localized to mitochondrial cristae. Proc Natl Acad Sci U $S$ A 105, 13145-13150.

[67] Crouch PJ, Blake R, Duce JA, Ciccotosto GD, Li QX, Barnham KJ, Curtain CC, Cherny RA, Cappai R, Dyrks T, Masters CL, Trounce IA (2005) Copper-dependent inhibition of human cytochrome $\mathrm{c}$ oxidase by a dimeric conformer of amyloid-beta1-42. J Neurosci 25, 672-679.

[68] Takuma K, Yao J, Huang J, Xu H, Chen X, Luddy J, Trillat AC, Stern DM, Arancio O, Yan SS (2005) ABAD enhances Abeta-induced cell stress via mitochondrial dysfunction. FASEB J 19, 597-598.

[69] Yan Y, Liu Y, Sorci M, Belfort G, Lustbader JW, Yan SS, Wang C (2007) Surface plasmon resonance and nuclear magnetic resonance studies of ABAD-Abeta interaction. Biochemistry 46, 1724-1731.

[70] Xie Y, Deng S, Chen Z, Yan S, Landry DW (2006) Identification of small-molecule inhibitors of the Abeta-ABAD interaction. Bioorg Med Chem Lett 16, 4657-4660.

[71] Du H, Guo L, Fang F, Chen D, Sosunov AA, McKhann GM, Yan Y, Wang C, Zhang H, Molkentin JD, Gunn-Moore FJ, Vonsattel JP, Arancio O, Chen JX, Yan SD (2008) Cyclophilin $\mathrm{D}$ deficiency attenuates mitochondrial and neuronal perturbation and ameliorates learning and memory in Alzheimer's disease. Nat Med 14, 1097-1105.

[72] Du H, Guo L, Zhang W, Rydzewska M, Yan S (2009) Cyclophilin D deficiency improves mitochondrial function and learning/memory in aging Alzheimer disease mouse model. Neurobiol Aging, in press.

[73] Falkevall A, Alikhani N, Bhushan S, Pavlov PF, Busch K, Johnson KA, Eneqvist T, Tjernberg L, Ankarcrona M and Glaser, E (2006) Degradation of the amyloid beta-protein by 
the novel mitochondrial peptidasome, PreP. J Biol Chem 281, 29096-29104.

[74] Stahl A, Moberg P, Ytterberg J, Panfilov O, Brockenhuus Von Lowenhielm H, Nilsson F, Glaser E (2002) Isolation and identification of a novel mitochondrial metalloprotease (PreP) that degrades targeting presequences in plants. J Biol Chem 277, 41931-41939.

[75] Moberg P, Stahl A, Bhushan S, Wright SJ, Eriksson A, Bruce BD, Glaser E (2003) Characterization of a novel zinc metalloprotease involved in degrading targeting peptides in mitochondria and chloroplasts. Plant J 36, 616-628.

[76] Stahl A, Nilsson S, Lundberg P, Bhushan S, Biverstahl H, Moberg P, Morisset M, Vener A, Maler L, Langel U, Glaser E (2005) Two novel targeting peptide degrading proteases, PrePs, in mitochondria andchloroplasts, so similar and still different. J Mol Biol 349, 847-860.

[77] Kurochkin IV (2001) Insulin-degrading enzyme: embarking on amyloid destruction. Trends Biochem Sci 26, 421-425.

[78] Selkoe DJ (2001) Clearing the brain's amyloid cobwebs. Neuron 32, 177-180.

[79] Tanzi RE, Moir RD, Wagner SL (2004) Clearance of Alzheimer's Abeta peptide: the many roads to perdition. Neuron 43, 605-608.

[80] Anandatheerthavarada HK, Biswas G, Robin MA, Avadhani NG (2003) Mitochondrial targeting and a novel transmembrane arrest of Alzheimer's amyloid precursor protein impairs mitochondrial function in neuronal cells. J Cell Biol 161, 41-54.

[81] Hansson CA, Frykman S, Farmery MR, Tjernberg LO, Nilsberth C, Pursglove SE, Ito A, Winblad B, Cowburn RF, Thyberg J, Ankarcrona M (2004) Nicastrin, presenilin, APH-1, and PEN-2 form active gamma-secretase complexes in mitochondria. J Biol Chem 279, 51654-51660.

[82] Muresan V, Varvel NH, Lamb BT, Muresan Z (2009) The cleavage products of amyloid-beta precursor protein are sorted to distinct carrier vesicles that are independently transported within neurites. $J$ Neurosci $\mathbf{2 9}, 3565-3578$.

[83] Area-Gomez E, de Groof AJ, Boldogh I, Bird TD, Gibson GE, Koehler CM, Yu WH, Duff KE, Yaffe MP, Pon LA, Schon EA (2009) Presenilins are enriched in endoplasmic reticulum membranes associated with mitochondria. Am J Pathol 175, 1810-1816.

[84] Roses AD, Lutz MW, Amrine-Madsen H, Saunders AM, Crenshaw DG, Sundseth SS, Huentelman MJ, WelshBohmer KA, Reiman EM (2009) A TOMM40 variablelength polymorphism predicts the age of late-onset Alzheimer's disease. Pharmacogenomics $J$, in press.

[85] Chang S, ran Ma T, Miranda RD, Balestra ME, Mahley RW, Huang Y (2005) Lipid- and receptor-binding regions of apolipoprotein E4 fragments act in concert to cause mitochondrial dysfunction and neurotoxicity. Proc Natl Acad Sci U S A 102, 18694-18699.

[86] Sayre LM, Perry G, Smith MA (2008) Oxidative stress and neurotoxicity. Chem Res Toxicol 21, 172-188.

[87] Querfurth HW, LaFerla FM (2010) Alzheimer's disease. $N$ Engl J Med 362, 329-344.

[88] Winblad B, Palmer K, Kivipelto M, Jelic V, Fratiglioni L, Wahlund LO, Nordberg A, Backman L, Albert M, Almkvist O, Arai H, Basun H, Blennow K, de Leon M, DeCarli C, Erkinjuntti T, Giacobini E, Graff C, Hardy J, Jack C, Jorm A, Ritchie K, van Duijn C, Visser P, Petersen RC (2004) Mild cognitive impairment-beyond controversies, towards a consensus: report of the International Working Group on Mild Cognitive Impairment. J Intern Med 256, 240-246.
[89] Praticò D, Sung S (2004) Lipid peroxidation and oxidative imbalance: early functional events in Alzheimer's disease. $J$ Alzheimers Dis 6, 171-175.

[90] Rinaldi P, Polidori MC, Metastasio A, Mariani E, Mattioli P, Cherubini A, Catani M, Cecchetti R, Senin U, Mecocci P (2003) Plasma antioxidants are similarly depleted in mild cognitive impairment and in Alzheimer's disease. Neurobiol Aging 24, 915-919.

[91] Nishida Y, Yokota T, Takahashi T, Uchihara T, Jishage K, Mizusawa H (2006) Deletion of vitamin E enhances phenotype of Alzheimer disease model mouse. Biochem Biophys Res Commun 350, 530-536.

[92] Smith RA, Porteous CM, Gane AM, Murphy MP (2003) Delivery of bioactive molecules to mitochondria in vivo. Proc Natl Acad Sci U S A 100, 5407-5412.

[93] Murphy MP, Smith RA (2007) Targeting antioxidants to mitochondria by conjugation to lipophilic cations. Anпи Rev Pharmacol Toxicol 47, 629-656.

[94] Leo S, Szabadkai G, Rizzuto R (2008) The mitochondrial antioxidants $\operatorname{MitoE}(2)$ and $\operatorname{MitoQ}(10)$ increase mitochondrial $\mathrm{Ca}(2+)$ load upon cell stimulation by inhibiting $\mathrm{Ca}(2+)$ efflux from the organelle. Ann N Y Acad Sci 1147, 264-274.

[95] Ricciarelli R, Argellati F, Pronzato MA, Domenicotti C (2007) Vitamin E and neurodegenerative diseases. Mol Aspects Med 28, 591-606.

[96] Isaac MG, Quinn R, Tabet N (2008) Vitamin E for Alzheimer's disease and mild cognitive impairment. Cochrane Database Syst Rev, CD002854.

[97] Brigelius-Flohe R, Traber MG (1999) Vitamin E: function and metabolism. FASEB J 13, 1145-1155.

[98] Sen CK, Khanna S, Rink C, Roy S (2007) Tocotrienols: the emerging face of natural vitamin E. Vitam Horm 76, 203-261.

[99] Mangialasche F, Kivipelto M, Mecocci P, Rizzuto D, Palmer K, Winblad B, Fratiglioni L (2010) High plasma levels of vitamin $\mathrm{E}$ forms and reduced Alzheimer's disease risk in advanced age. J Alzheimers Dis, in press.

[100] Morris MC, Evans DA, Tangney CC, Bienias JL, Wilson RS, Aggarwal NT, Scherr PA (2005) Relation of the tocopherol forms to incident Alzheimer disease and to cognitive change. Am J Clin Nutr 81, 508-514.

[101] Gutierrez AD, de Serna DG, Robinson I, Schade DS (2009) The response of gamma vitamin $\mathrm{E}$ to varying dosages of alpha vitamin E plus vitamin C. Metabolism 58, 469-478.

[102] Khanna S, Patel V, Rink C, Roy S, Sen CK (2005) Delivery of orally supplemented alpha-tocotrienol to vital organs of rats and tocopherol-transport protein deficient mice. Free Radic Biol Med 39, 1310-1319.

[103] Bjelakovic G, Nikolova D, Gluud LL, Simonetti RG, Gluud C (2007) Mortality in randomized trials of antioxidant supplements for primary and secondary prevention: systematic review and meta-analysis. JAMA 297, 842-857.

[104] Yang X, Yang Y, Li G, Wang J, Yang ES (2008) Coenzyme Q10 attenuates beta-amyloid pathology in the aged transgenic mice with Alzheimer presenilin 1 mutation. J Mol Neurosci 34, 165-171.

[105] Matveeva IA (1983) [Action of dimebon on histamine receptors]. Farmakol Toksikol 46, 27-29.

[106] Lermontova NN, Lukoyanov NV, Serkova TP, Lukoyanova EA, Bachurin SO (2000) Dimebon improves learning in animals with experimental Alzheimer's disease. Bull Exp Biol Med 129, 544-546.

[107] Bachurin S, Bukatina E, Lermontova N, Tkachenko S, Afanasiev A, Grigoriev V, Grigorieva I, Ivanov Y, Sablin S, Zefirov N (2001) Antihistamine agent Dimebon as a novel 
neuroprotector and a cognition enhancer. Ann N Y Acad Sci 939, 425-435

[108] Wu J, Li Q, Bezprozvanny I (2008) Evaluation of Dimebon in cellular model of Huntington's disease. Mol Neurodegener 3, 15 .

[109] Doody RS, Gavrilova SI, Sano M, Thomas RG, Aisen PS, Bachurin SO, Seely L, Hung D (2008) Effect of dimebon on cognition, activities of daily living, behaviour, and global function in patients with mild-to-moderate Alzheimer's disease: a randomised, double-blind, placebo-controlled study. Lancet 372, 207-215.

[110] Schaffhauser H, Mathiasen JR, Dicamillo A, Huffman MJ, Lu LD, McKenna BA, Qian J, Marino MJ (2009) Dimebolin is a 5-HT6 antagonist with acute cognition enhancing activities. Biochem Pharmacol 78, 1035-1042.

[111] Grigorev VV, Dranyi OA, Bachurin SO (2003) Comparative study of action mechanisms of dimebon and memantine on AMPA- and NMDA-subtypes glutamate receptors in rat cerebral neurons. Bull Exp Biol Med 136, 474-477.

[112] Lermontova NN, Redkozubov AE, Shevtsova EF, Serkova TP, Kireeva EG, Bachurin SO (2001) Dimebon and tacrine inhibit neurotoxic action of beta-amyloid in culture and block L-type Ca(2+) channels. Bull Exp Biol Med 132, 1079-1083.

[113] Bachurin SO, Shevtsova EP, Kireeva EG, Oxenkrug GF, Sablin SO (2003) Mitochondria as a target for neurotoxins and neuroprotective agents. Ann N Y Acad Sci 993, 334-344; discussion 345-339.

[114] Zhang S, Hedskog L, Hansson Petersen CA, Winblad B, Ankarcrona M (2010) Dimebon (latrepirdine) enhances mitochondrial function and protects neuronal cells from death. $J$ Alzheimers Dis 21, in press.

[115] Yamashita M, Nonaka T, Arai T, Kametani F, Buchman VL, Ninkina N, Bachurin SO, Akiyama H, Goedert M, Hasegawa M (2009) Methylene blue and dimebon inhibit aggregation of TDP-43 in cellular models. FEBS Lett 583, 2419-2424.

[116] Steele JW, Kim SH, Cirrito JR, Verges DK, Restivo JL, Westaway D, Fraser P, Hyslop PS, Sano M, Bezprozvanny I, Ehrlich ME, Holtzman DM, Gandy S (2009) Acute dosing of latrepirdine (Dimebon), a possible Alzheimer therapeutic, elevates extracellular amyloid-beta levels in vitro and in vivo. Mol Neurodegener 4, 51. 